\title{
PAYING AND SAVING IN GOLD IN THE ROMAN ARMY \\ The aureus of Vespasian from Războieni-Cetate and the evidence of gold coins in Roman Dacia (Romania)
}

\begin{abstract}
Starting from a recently discovered gold coin, aureus, of Vespasian in the military environment of Războieni-Cetate, Romania (in former Roman Dacia), the present study gathered the evidence of similar finds from the territory of former Roman Dacia. A comparative analysis with the evidence from well-documented sites from other Roman provinces (e.g. Britannia) and from ancient literary sources may lead to the conclusion that the military payments could have been made in gold coin, as well as the military would like to keep/save money in the same metal - easy to carry a highest value.

Another aspect revealed by this study is the dating of an archaeological context based on numismatic evidence. The coin under study here together with the historical background of the site where it was found indicate that the coin could have been lost almost 30 years later from the date of minting.

Keywords: aureus, Războieni-Cetate, Roman Dacia, military pay.
\end{abstract}

ince 2016, systematic archaeological excavations were resumed in Războieni-Cetate (Alba County, Romania). ${ }^{1}$ The archaeological site is located on the valley of the Middle Mureș River on a high terrace in the north-western part of the modern village. On the territory of the former Roman province of Dacia, the site was located on the central-north part (see maps 1-2). The site hosts the auxiliary fort of Ala I Batavorum milliaria and the adjacent civilian settlement (vicus militaris) from the Roman era (see map 3). ${ }^{2}$ A large amount of pottery and various small finds have been collected over time and are now part of the local middle school collection. ${ }^{3}$

As a first step on the systematic investigation, in order to form out an overview of the site, a non-intrusive geo-magnetic scanning was undertaken. The published results revealed the development of the vicus on the northwestern part of the auxiliary fort. ${ }^{4}$

With the permission of one of the land owners, this sector of the

\footnotetext{
${ }^{1}$ The research was carried out by a team of the National Union Museum Alba Iulia, Romania and the Babeș-Bolyai University Cluj-Napoca, Romania: George Bounegru, Rada Varga, Imola Boda and Cristina Crizbășan (University of Exeter, United Kingdom, graduate student).

2 POPOVICI/VARGA 2010, 45-48.

${ }^{3}$ For coin finds at Războieni, see ARDEVAN/VARGA 2010, 183-199.

${ }^{4}$ MISCHKA/RUBEL/VARGA 2018, 377-405.
}

\section{Cristian GĂZDAC}

Institute of Archaeology Cluj-Napoca cgazdac2000@yahoo.co.uk

\section{George BOUNEGRU}

Union National Museum Alba Iulia bounegrugvviziru@yahoo.com

\section{Rada VARGA}

Center for the Roman Studies Cluj-Napoca radavarga@gmail.com

DOI: $10.14795 /$ j.v7i2.535

ISSN 2360 - 266X

ISSN-L 2360 - 266X 
northern vicus, was available for systematic archaeological investigation. The excavation started at a spot located $25 \mathrm{~m}$ from the north-west corner of the fort. Here, the geo-physical map clearly revealed a building ( $20 \times 25 \mathrm{~m})$, conventionally named Edifice I.

The research focused on the building planimetry and phase(s) of inhabitation. The archaeological investigation reached the conclusion that the building belonged to the first phase of Roman habitation in this area. During the archaeological campaigns the eastern corner was uncovered, part of the north-eastern perimeter wall and, partly, the south-east corner one. The foundations were built with stone blocks and clay, with no traces of mortar, representing, in fact the foundation's sole (two apses were preserved) with a width of $1 \mathrm{~m}$, over which a wooden elevation must have been built. Numerous tile fragments indicate the existence of a tile roof. The building was partially destroyed by fire, the traces of this combustion being visible on the beaten clay floor in at least two rooms, including the kitchen (which might have been the starting point of the disaster). Outside the building, a layer of yellow clay was identified, probably, used for levelling the ground for the building's foundations. The recovered archaeological material is extremely rich and includes, in addition to a large amount of pottery, ${ }^{5}$ numerous artefacts from the small finds' category (coins, bone pieces, ornaments, toys, fragments of lamps and patterns, poinçons for decorating pottery, etc.). Import and generally luxury pieces do not lack, ${ }^{6}$ testifying for the prosperity of the habitation flourished near the fort of a well-paid ala milliaria.

Thisbuildingwaslocatednexttoaroad,archaeologically visible in the form of successive layers of gravel, probably with consecutive restorations. Stratigraphically, the first gravel layers descend below the building's foundation, implying and earlier dating, in connection to the fort. As only 2 sqm of this road were investigated, and it is not visible on the geophysical survey (thus, a secondary/tributary road/path), at the moment, the precise route may not be established. Most likely, it led north of the fort. Beneath the road, a layer of black earth, with burnt charcoal pigments was discovered. Some Roman artefacts were also present. Below this level, at $-1.12 \mathrm{~m}$, there is a black-brown layer, compact and sterile from the archaeological point of view.
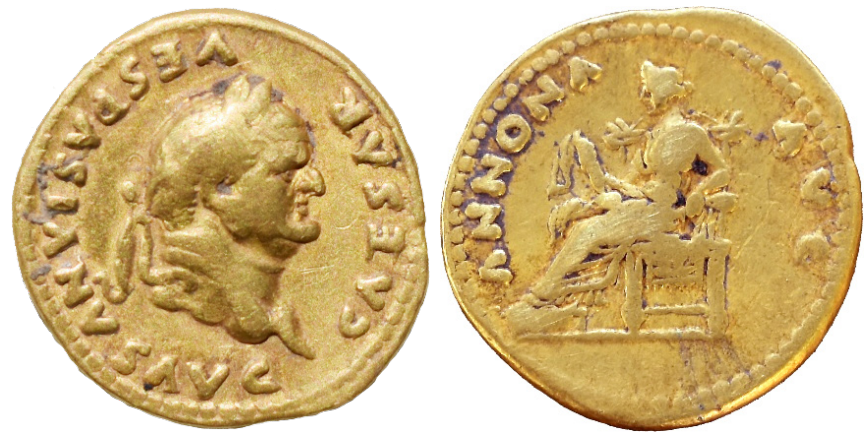

Fig. 1. Aureus of Vespasian (Rome, AD 77-78) discovered at Războieni.

\footnotetext{
${ }^{5}$ The geo-magnetic surveys have indicated the presence of numerous pottery kilns, underlining the presence of a local production centre. Its existence is also supported by the large quantity of waste and moulds coming from the same are.

${ }^{6}$ VARGA/CRIZBĂȘAN 2019.
}

During the campaign of 2018, a gold coin, aureus, came to light, beneath the gravel layer of the first phase of the road. Most likely, the coin was lost while the road was built.

\section{VESPASIANVS}

Denomination: aureus

Axis: 6; D: $19.1 \mathrm{~mm}$; W: 6.75 gr.

Mint: Rome

Dating: AD 77-78

Obverse: CAESAR VESPASIANVS AVG(ustus)

\section{$R v: \quad$ ANNONA - AVG(usti)}

Annona, draped, seated left on throne, feet on stool, holding on her lap a sack of corn-ears open, holding the ties in her hands.

Reference: RIC II.1, no. 963

Inv. No.: National Union Museum Alba Iulia, 2020

Archaeological context: County Alba, Războieni, "Cetate" [Chester], vicus, the Edifice I, $25 \mathrm{~m}$ from the auxiliary fort north-western corner; area 2, quadrant 2, $-1.12 \mathrm{~m}$; 03.08.2018

What one can see in this single gold coin find and its archaeological context?

The findspot is located on the vicus militaris surface but only $25 \mathrm{~m}$ from the auxiliary fort (see map 3). Furthermore, the stratigraphy at the place indicates that the coin was actually found in the road substructure that pre-date the building, that was the main task of the archaeological investigation. This may allow to assume that the person who lost the coin was most likely a military.

It has been frequently argued that the Roman army was given their pay in bronze, a view supported by the spectrum of single coin finds in the military sites ${ }^{7}$, although, the written sources mentioned the military payments salaries and donatives being counted in denarii (silver). ${ }^{8}$

As R. Wolters clearly demonstrated that the amount of payments counted in silver could actually have been paid also in gold coins to facilitate the payment: "...a stipendium of 75 denarii could theoretically be paid in form of either 3 gold pieces, 75 silver pieces, 300 large bronze pieces (sesterces) or 1200 normal bronze pieces (asses) respectively. [...] Three aurei together weighed approximately 24 grams whereas a pay of 75 denarii in silver pieces amounted to a weight of nearly 300 grams. Paid in form of asses the amount to be paid to each soldier on payday added up to about 13 kilograms." ${ }^{\prime 9}$

According to L. Wierschowski, the yearly payment of only one legion was $1,642,000$ denarii, that means a weight of over 6,200 kilograms of silver or nearly 300,000 kilograms of asses a year, or 2,000 kilograms of silver or 100,000 kilograms of bronze per payday respectively. ${ }^{10}$

Taking into account this quantity/weight and also the transportation conditions of such it, payment in gold coins may have been regarded by authorities as an alternative,

See the discussion and bibliography on the topic in WOLTERS 2001, 579-

${ }^{8}$ SPEIDEL 1992, 87-106; ALSTON 1994, 113-123; DUNCAN-JONES 1994, 39-41; WATSON 1994, 108-110.

9 WOLTERS 2001, 580.

10 WIERSCHOWSKI 1984, 213, apud WOLTERS 2001, 580-581. 
when possible.

In a certain situation, like the siege of a city, the payment in silver and gold may also have a psychological impact, a benefit for Roman soldiers and to intimidate the enemy, ${ }^{11}$ as Flavius Josephus mentioned such an episode at the siege of Jerusalem by Titus: "The appointed day having arrived for the distribution of the soldiers' pay, he ordered his officers to parade the forces and count out the money to each man in full view of the enemy. So, the troops, as was their custom, drew forth their arms from the cases in which till now they had been covered and advanced clad in mail, the cavalry leading their horses which were richly caparisoned. The area in front of the city gleamed far and wide with silver and gold, and nothing was more gratifying to the Romans, or more awe-inspiring to the enemy, than that spectacle."12

A further argument that military payments could have been delivered in gold may be considered the far higher frequency of single gold finds and gold hoards at military forts than urban, suburban or rural sites from Britannia. ${ }^{13}$

Although the number of single gold coin finds from the territory of Roman Dacia (in nowadays Romania) is much lower than the above-mentioned province, their spectrum suggests a similar pattern (see appendix and map 4).

At the moment, 31 aurei are known as single gold finds found on the territory of the former Roman province of Dacia. More than a half, 19 coins, were found at military units: legionary fort 2, auxiliary forts 16 , border watchtower 1. Eight coins were discovered at urban and suburban sites, four at rural sites and two from findspots of unknown type of settlement. (see appendix and map 4). It must be pointed

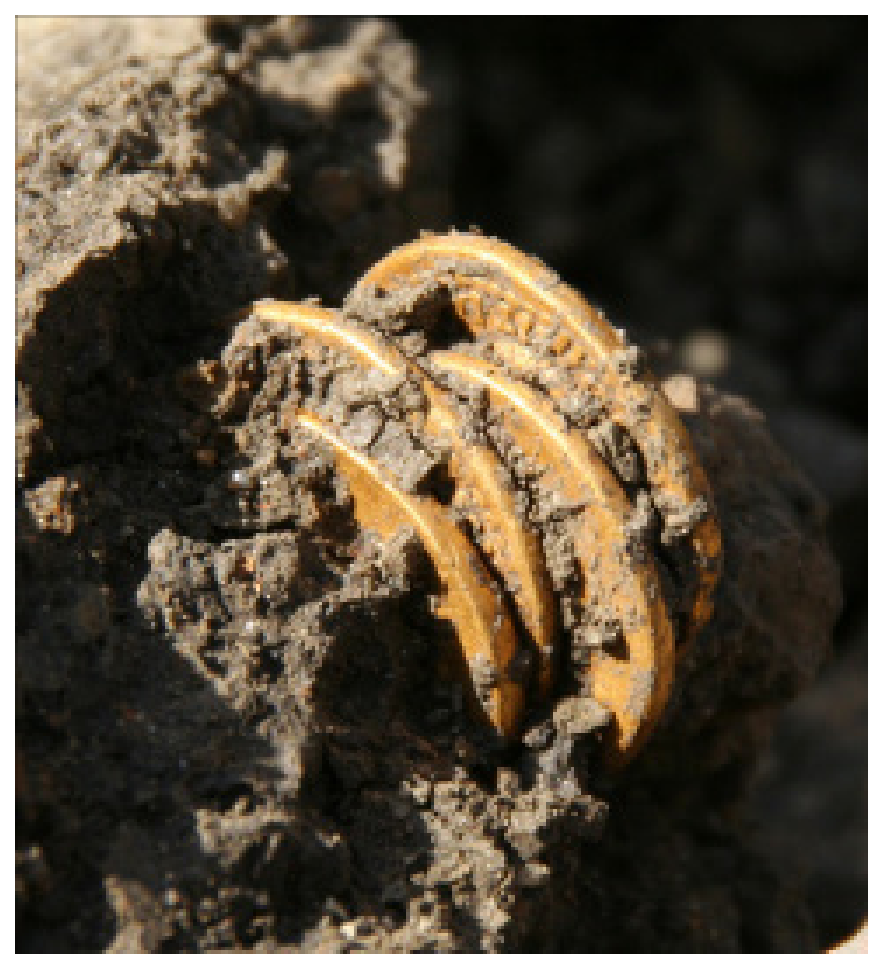

Fig. 2. The aurei at the fort of Răcari at the moment of discovery. TEODOR 2020, 36, fig. 2.

\footnotetext{
11 HOWGEGO 2015, 126.

${ }_{12}$ Flavius Josephus, De bello Judaico, 5.9.1 (trans. Thackeray), apud HOWGEGO 2015, 126.

13 BLAND/LORIOT 2010, 34-51.
}

out that in the cases of aurei found at urban sites/areas, such as Alba Iulia and Moigrad, those sites have also known a strong military presence.

The aureus of Vespasian found in the very close vicinity of the cavalry fort from Războieni (see map 3) is increasing the number of gold coins provided by the military environment in Roman Dacia.

It is worth mentioning here, that recently has been published an important discovery, for the present topic. In the auxiliary fort from Răcari (Dolj County, Romania), located in the south-western part of former Roman Dacia territory, archaeological investigations brought to light four aurei stuck together (see map 4). ${ }^{14}$

The last case is one more argument to support the theory that military pay could have been done in gold coins, or, at least, the soldiers like to keep/save in gold coins some of their pay.

Another aspect that this monetary discovery has made us to take into account is the date of minting of these coins and the historical background of the contexts in which they were found.

The aureus found at Războieni was minted in Rome in AD 77-78 during the reign of Vespasian. The finding spot provides no evidence of a pre-Roman presence. As it is a well-known historical fact, Dacia has been conquered by the Romans following two fiercely fought wars - AD 101-102 and AD 105-106 - during the reign of Trajan, ending up in a military occupation of the largest part of the former Dacian kingdom which soon became a province.

Archaeologically, the aureus of Vespasian was, in fact found, in a context that cannot be dated earlier then $\mathrm{AD}$ 106. And the case from Războieni is not an exception. In fact, we face here another pattern regarding the length of coin circulation, the case of mid- $1^{\text {st }}$ century AD aurei. Again, the analysis of gold finds from the military sites from Roman Dacia, indicates that the largest number of aurei belong to Vespasian and his family (8), followed by Nero (3) (see Appendix). And this spectrum is fully covered by that discovery of four aurei in the fort of Răcari, mentioned above. They were all issues of Vespasian (1 Vespasian, 3 Domitian Caesar). ${ }^{15}$ This example indicate that earlier gold issues were not isolated pieces among the new ones but they could all stay together in circulation either subject for a payment or worth saving. At the same time, when the stratigraphic context it is known, Războieni, Răcari ${ }^{16}$ and Buciumi, ${ }^{17}$ the Vespasian aurei were found in the earliest layers only, Trajanic-Hadrianic phases of the forts.

Is this a specific pattern for gold coinage to have a longer period of circulation than the coins of other metals, silver, brass, copper? One may answer affirmatively, as it is a normal human behaviour to keep your wealth in items that will keep their high value for a longer period.

However, the archaeological context, the stratigraphy, may come with situations that can prove otherwise.

In the case of the forum of colonia Ulpia Traiana Sarmizegetusa in Roman Dacia (nowadays, Sarmizegetusa,

\footnotetext{
14 TEODOR 2020, 33-41; https://chre.ashmus.ox.ac.uk/hoard/8959.

5 TEODOR 2020, 38; https://chre.ashmus.ox.ac.uk/hoard/8959.

16 TEODOR 2020, 37.

7 GĂZDAC/PRIPON 2012, 47, no. 39.
} 
Hunedoara County, Romania), the excavation by contexts and the dating of phases of this complex according to epigraphic and artefacts evidence have shown that in the context of the earliest phase of the forum (reign of Trajanbeginning of Hadrian) over $60 \%$ (23 pieces) of the coins were issued before the conquest of Dacia. ${ }^{18}$ Among them, a plated drachm of Apollonia dated in the $1^{\text {st }}$ century BC. ${ }^{19}$ From these 23 coins 15 are asses minted from Augustus (16 BC) to Nerva (AD 97). ${ }^{20}$ There are 7 denarii (one plated) of which 4 were issued by Mark Antony - known to stay longer in circulation for their low fineness of silver - and 2 denarii of Vespasian. ${ }^{21}$ The layer, in which these coins were found, represents the levelling layer after the demolition of the wooden phase in order to build the stone forum. ${ }^{22}$

The higher number of Flavian aurei finds followed by the ones of Nero than more contemporary ones with the conquest of Dacia (Trajan 1) can be explain within the monetary policy regarding the gold coinage in the times of Nero and Vespasian. There was a strong production of gold coins from the reign of Nero to the one of Vespasian. ${ }^{23}$

In conclusion, the discovery of an aureus of Vespasian in a military context on the territory of the former Roman province of Dacia it can be explained as part of a general pattern in the Roman Empire of military paid being done perhaps in certain situations and amounts - in gold coinage and/or, at the same time, the possibility of keeping/saving/ hoarding money by the military in this valuable metal.

The specificity of such discovery comes from utility of such a coin for dating the archaeological context. It must be accepted for the archaeologist, numismatist and historian that a coin may stay a long time in circulation after being minted for various reason (metal value, face value, hazard). From this point of view, the Roman sites from Romania (the Roman Dacia part) can be of some help with a distinguished chronological segment of AD 106-270/275.

\section{ACKNOLEDGMENTS}

The technical details of the coin (axis, weight, diameter) were provided by Ovidiu Oargă (Union National Museum Alba Iulia) to whom we express our gratitude.

\section{REFERENCES}

\section{ALSTON 1994}

Alston, R., Roman Military Pay from Caesar to Diocletian, Journal of Roman Studies 84, 113-123.

ARDEVAN/VARGA 2010

Ardevan, R./Varga, R., Descoperiri monetare antice la Războieni (jud. Alba), Bibliotheca Historica et Archaeologica Universitatis Timisiensis 12, 183-199.

BLAND/LORIOT 2010

Bland, R./Loriot, X., Roman and Early Byzantine Gold Coins found in Britain and Ireland with an appendix of new finds from Gaul [Special publication Royal Numismatic Society (Great Britain) 46.] (London: Royal Numismatic Society).

DUNCAN-JONES 1994

Duncan-Jones, R., Money and Government in the Roman
Empire (Cambridge: University Press)

GĂZDAC/COCIȘ 2004

Găzdac, C./Cociș, S., Vlpia Traiana Sarmizegtusa (ClujNapoca: Mega).

GĂZDAC/PRIPON 2012

Găzdac, C./Pripon, E., Castrul auxiliar de la Buciumi (ClujNapoca: Mega).

\section{HOWGEGO 2015}

Howgego, Ch.: The circulation of the gold coinage of Vespasian struck in the East. In: Bland, R./Calomino, D. (eds.), Studies in ancient coinage in honour of Andrew Burnett (London: Spink), 126-137.

MISCHKA/RUBEL/VARGA 2018

Mischka, C./Rubel, Al./Varga, R., Das Lager der ala I Batavorum milliaria und sein vicus in Războieni-Cetate (Jud. Alba/ RO) - Geophysikalische Untersuchungen und historische Einordnungen, Archäologisches Korrespondenzblatt 48, 377405.

POPOVICI/VARGA 2010

Popovici, P./Varga, R., Ad Vatabos: monografie arheologică a localităţii Războieni-Cetate. (Cluj-Napoca: Mega).

SPEIDEL 1992

Speidel, M.A., Roman Army Pay Scales, Journal of Roman Studies 82, 87-106.

TEODOR 2020

Teodor, E.S., A small aurei deposit found in Răcari fort, Journal of Ancient History and Archaeology 7/1, 33-41.

VARGA/CRIZBĂȘAN 2019

Varga, R./Crizbășan, C., The impact of the Batavian auxiliaries on the community at Războieni-Cetate (Alba County). Case study: the ceramic artefacts. In: MihailescuBîrliba, L./Spickermann, W. (eds.), Roman Army and Local Society in the Limes Provinces of the Roman Empire. Papers of an International Conference, Iași, June 4th-6th, 2018 [Pharos. Studien zur griechisch-römischen Antike 42] (Rhaden/ Westfalien: Marie Leidorf), 139-162.

WATSON 1995

Watson, G.R., The Roman Soldier (Ithaca: Cornell University Press)

WIERSCHOWSKI 1984

Wierschowski, L., Heer und Wirtschaft. Das romische Heer der Prinzipatszeit als Wirtschaftsfaktor [Habelts Dissertationsdrucke. Reihe Alte Geschichte 20] (Bonn: Habelt).

WOLTERS 2000-2001

Wolters, R., Bronze, silver or gold? Coin finds and the pay of the Roman army, Zephyrus 53-54, 579-588. 


\section{APPENDIX. AUREI FINDS IN ROMAN DACIA BY THE TYPE OF SITES}

\section{Legionary fort}

1. Turda: aureus of Hadrian; ${ }^{24}$ aureus of Marcus Aurelius for Lucius Verus ${ }^{25}$

\section{Auxiliary forts}

1. Arutela/Călimănești: aureus of Domitian ${ }^{26}$

2. Bologa: aureus of Vespasian ${ }^{27}$

3. Boroșneu Mare: aureus of Nero; ${ }^{28}$ aureus of Titus ${ }^{29}$

4. Buciumi: aureus of Vespasian ${ }^{30}$

5. Cătunele: aureus of Septimius Severus ${ }^{31}$

6. Cășeiu: aureus of Vespasian ${ }^{32}$

7. Cristești: aureus of Trajan ${ }^{33}$

8. Gherla: aureus of $\mathrm{Nero}^{34}$

9. Gilău: aureus of Titus ${ }^{35}$

10. Moigrad: aureus of Vespasian for Domitian Caesar ${ }^{36}$

11. Moldova Veche: aureus of Titus ${ }^{37}$

12. Pojejena: aureus of $\mathrm{Nero}^{38}$

13. Războieni

14. Râșnov: aureus of Galba ${ }^{39}$

15. Sânpaul: aureus of Otho ${ }^{40}$

\section{Watchtower}

1. Negreni: aureus of Nero ${ }^{41}$

\section{Urban}

1. Alba Iulia: aureus of Trebonianus Gallus ${ }^{42}$

2. Moigrad: aureus of Nero; ${ }^{43}$ aureus of Vespasian for Domitian Caesar ${ }^{44}$

3. Turda: aureus of Antoninus Pius; ${ }^{45}$ aureus of Gordian III ${ }^{46}$

4. Zlatna: aureus of $\mathrm{Nero}^{47}$

\section{Suburban}

1. Densus: aureus of $\mathrm{Nero}^{48}$

2. Jac: aureus of Trajan ${ }^{49}$

\section{Rural settlement}

1. Band: aureus of Marcus Aurelius ${ }^{50}$

2. Caransebeș: aureus of Severus Alexander ${ }^{51}$

3. Gârbou: aureus of Vespasian ${ }^{52}$

4. Sovata: aureus of Vespasian ${ }^{53}$

\section{Unknown type of settlement}

1. Potoc: aureus of Titus ${ }^{54}$ https://chre.ashmus.ox.ac.uk/hoard/8955

https://chre.ashmus.ox.ac.uk/hoard/8957

https://chre.ashmus.ox.ac.uk/hoard/9177

https://chre.ashmus.ox.ac.uk/hoard/9126

https://chre.ashmus.ox.ac.uk/hoard/9132

https://chre.ashmus.ox.ac.uk/hoard/9133

https://chre.ashmus.ox.ac.uk/hoard/8954

https://chre.ashmus.ox.ac.uk/hoard/9178

32 https://chre.ashmus.ox.ac.uk/hoard/8803

https://chre.ashmus.ox.ac.uk/hoard/9124

${ }^{34}$ https://chre.ashmus.ox.ac.uk/hoard/9186

https://chre.ashmus.ox.ac.uk/hoard/8804

${ }^{36}$ https://chre.ashmus.ox.ac.uk/hoard/8953

https://chre.ashmus.ox.ac.uk/hoard/9187

https://chre.ashmus.ox.ac.uk/hoard/9193

https://chre.ashmus.ox.ac.uk/hoard/9196

https://chre.ashmus.ox.ac.uk/hoard/9200

${ }^{41}$ https://chre.ashmus.ox.ac.uk/hoard/9188
${ }^{42}$ https://chre.ashmus.ox.ac.uk/hoard/8949

3 https://chre.ashmus.ox.ac.uk/hoard/8952

${ }^{44}$ https://chre.ashmus.ox.ac.uk/hoard/13190

${ }_{45}$ https://chre.ashmus.ox.ac.uk/hoard/8956

${ }^{6}$ https://chre.ashmus.ox.ac.uk/hoard/8958

47 https://chre.ashmus.ox.ac.uk/hoard/9206

8 https://chre.ashmus.ox.ac.uk/hoard/9180

49 https://chre.ashmus.ox.ac.uk/hoard/

https://chre.ashmus.ox.ac.uk/hoard/9125

${ }^{51}$ https://chre.ashmus.ox.ac.uk/hoard/9136

2 https://chre.ashmus.ox.ac.uk/hoard/

${ }^{53}$ https://chre.ashmus.ox.ac.uk/hoard/9123

${ }_{54}$ https://chre.ashmus.ox.ac.uk/hoard/9194 


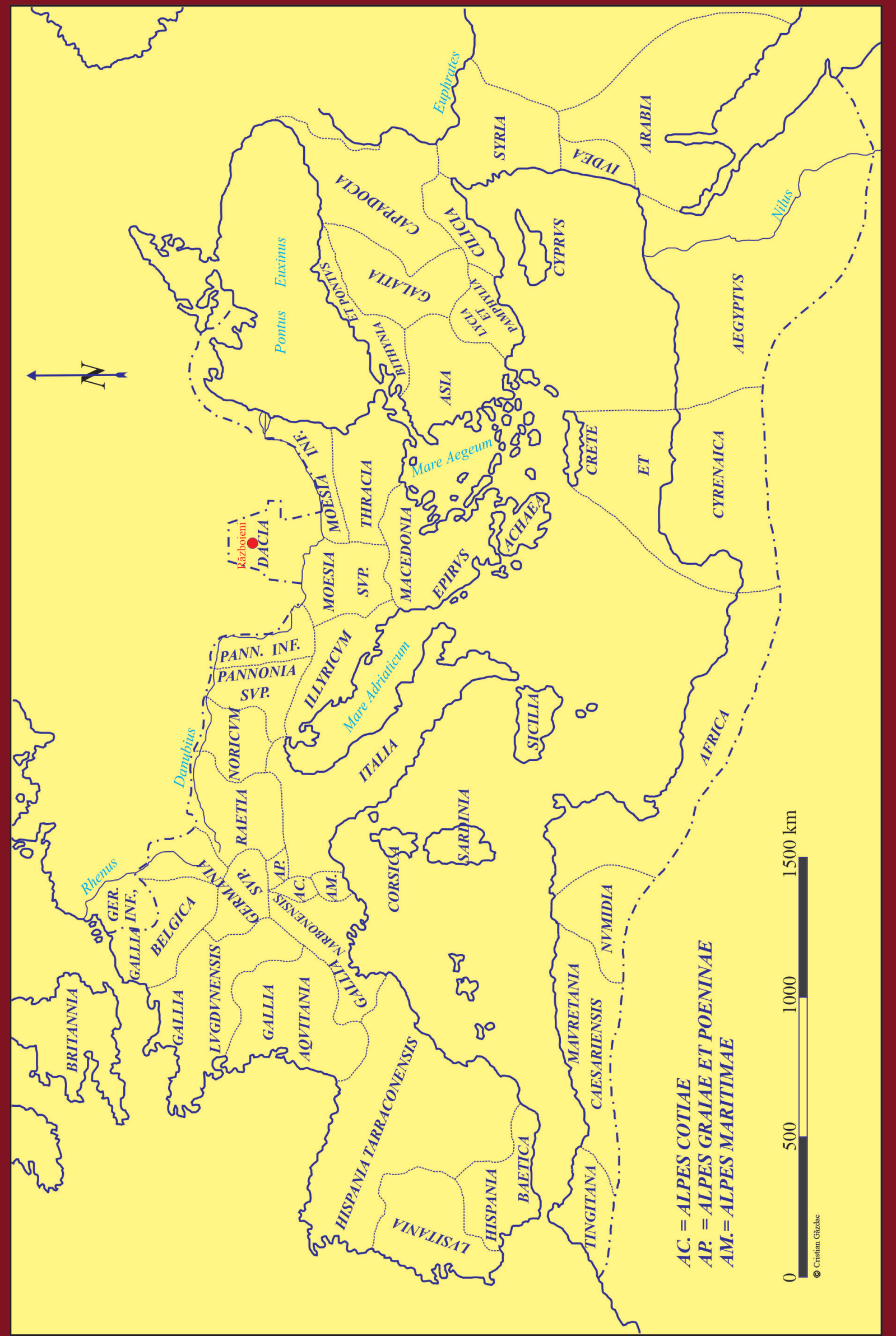

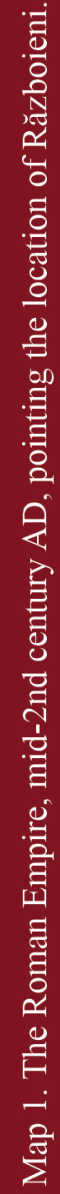




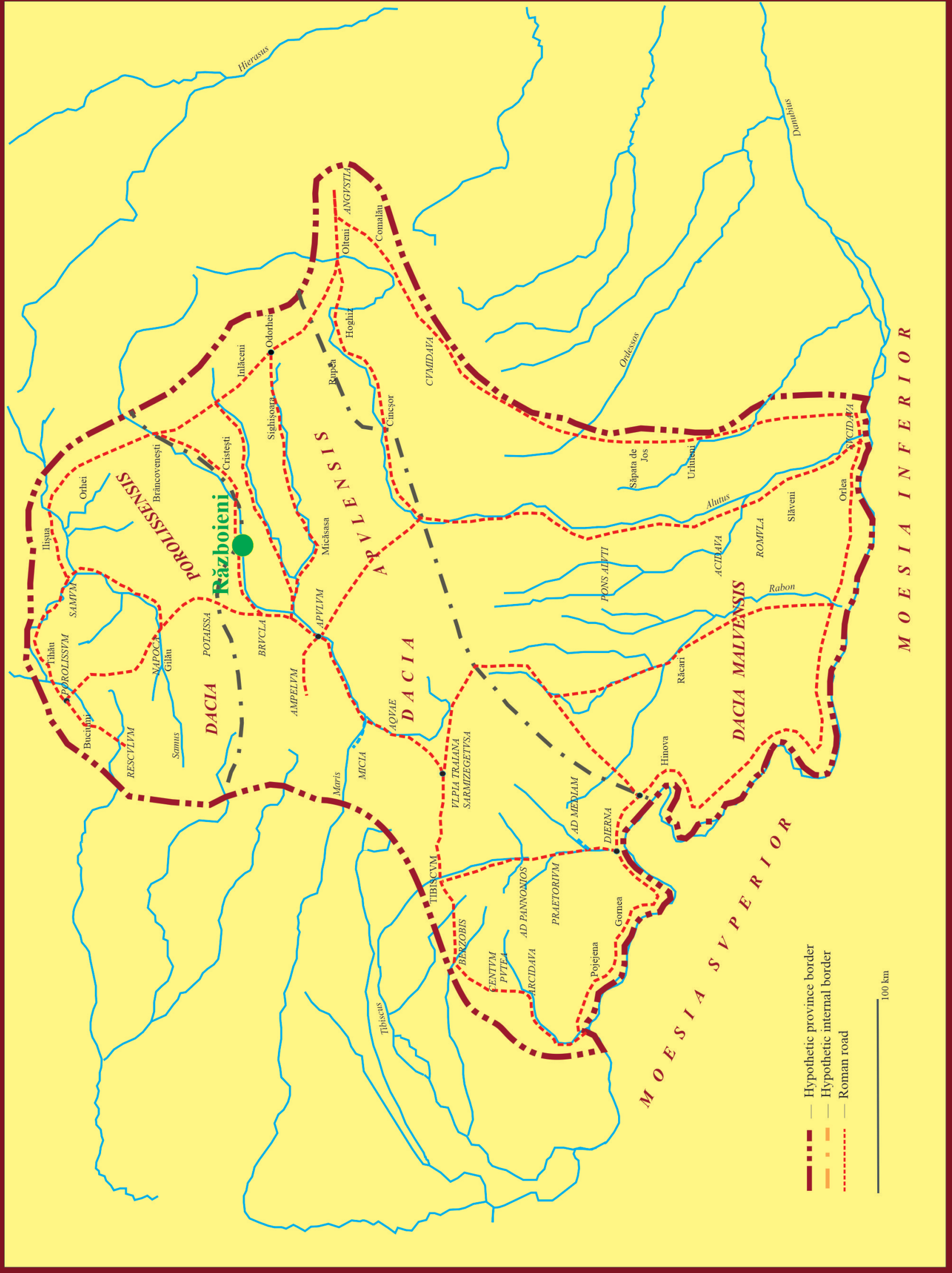

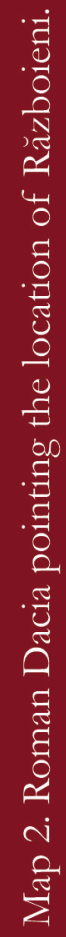




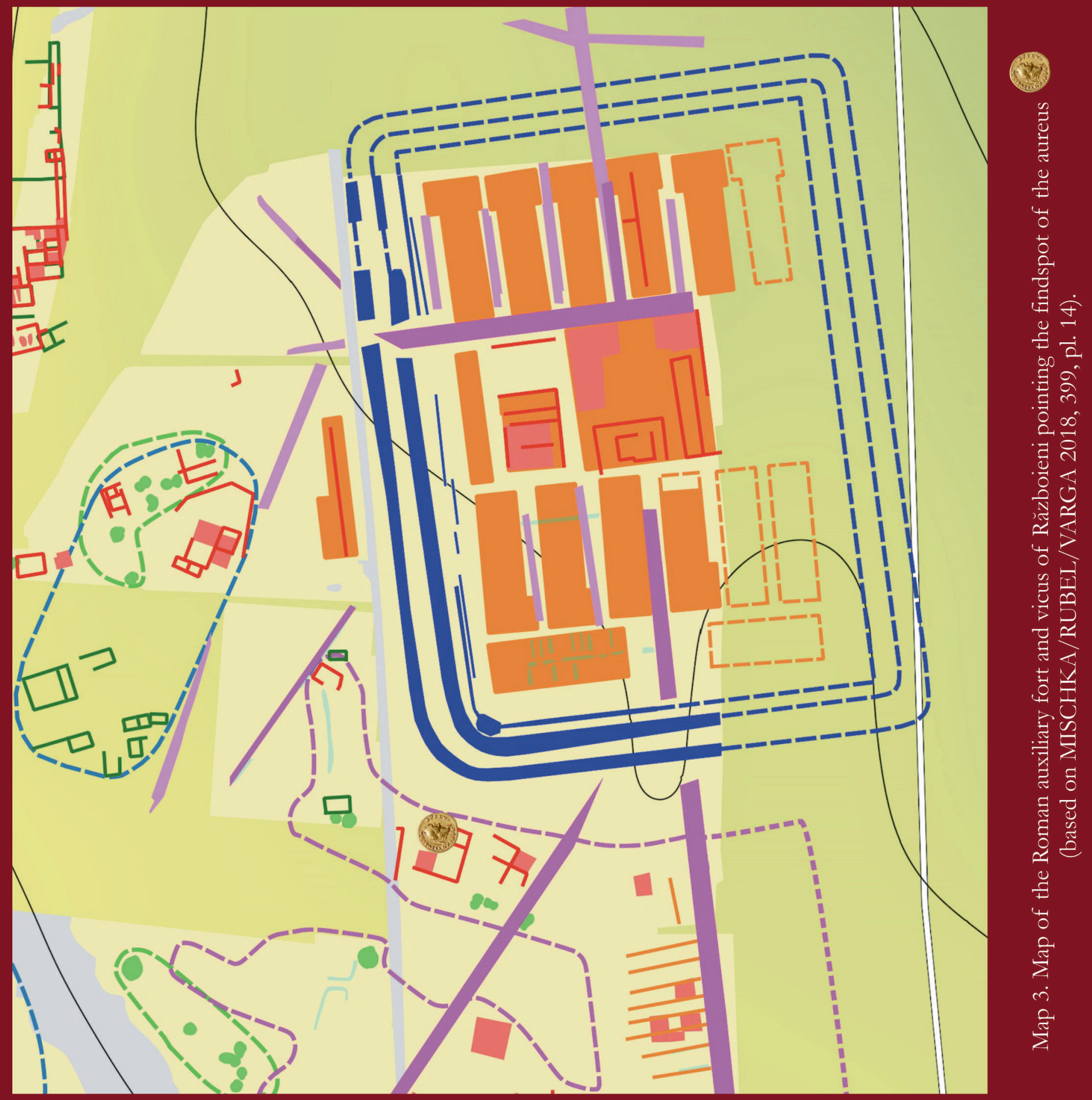




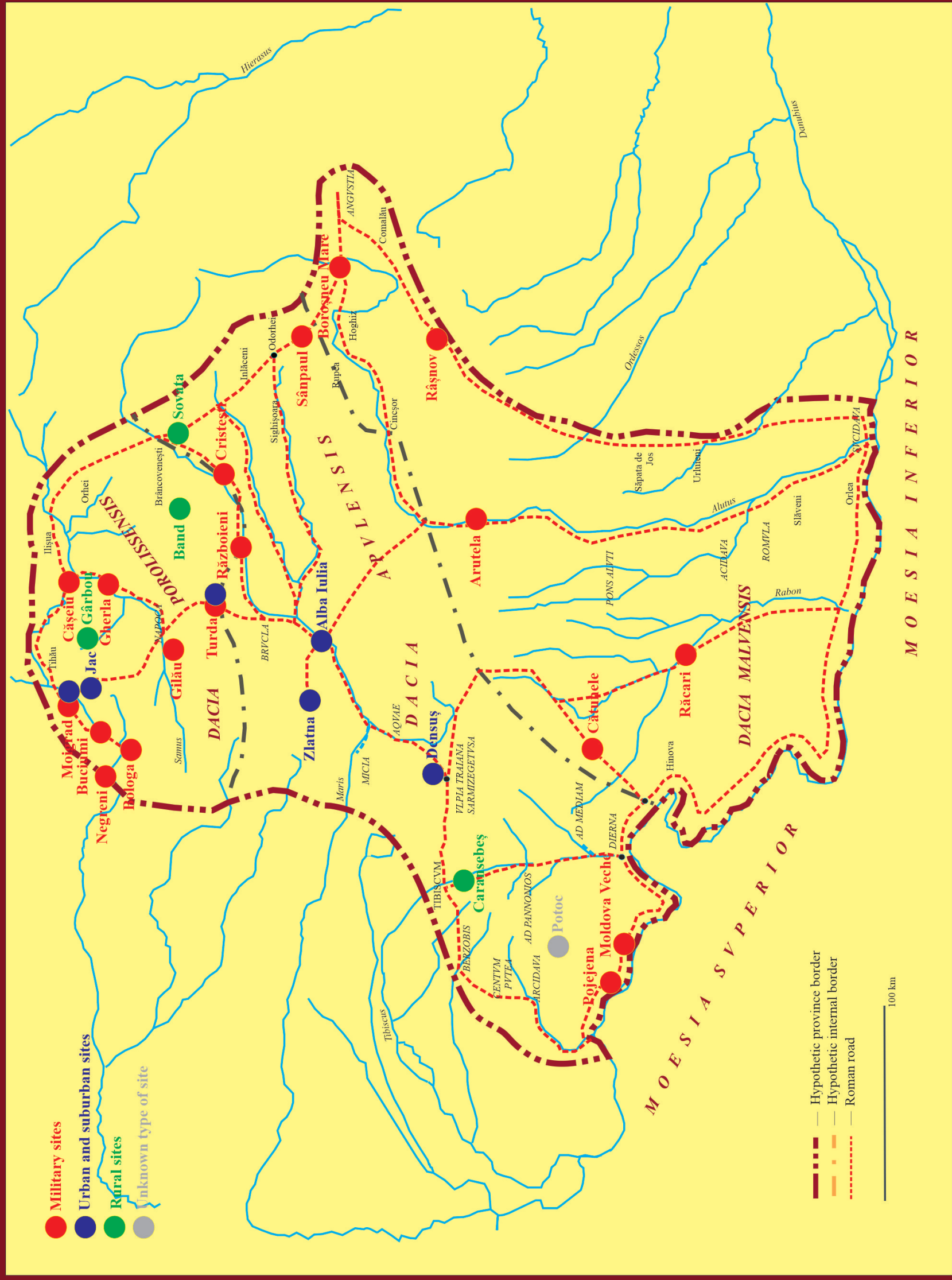

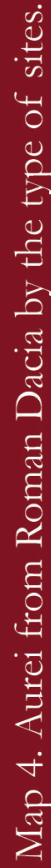

